\title{
Limbic encephalitis associated with potassium channel antibodies: demonstration of clinical and paraclinical responses to immunotherapy
}

\author{
Viktoria Kapina*, Fabienne Picard, Serge Vulliemoz, Maria Vargas, \\ Theodor Landis and Patrice Lalive
}

Address: Department of Neurology, HUG, University Hospital and Medical School of Geneva, Switzerland

* Corresponding author

from International Society on Brain and Behaviour: 3rd International Congress on Brain and Behaviour

Thessaloniki, Greece. 28 November - 2 December 2007

Published: 17 April 2008

Annals of General Psychiatry 2008, 7(Suppl I):S24I doi:I0.1 I86/I744-859X-7-SI-S24I

This abstract is available from: http://Www.annals-general-psychiatry.com/content/7/SI/S24 I

(C) 2008 Kapina et al.; licensee BioMed Central Ltd.

\section{Background}

Limbic encephalitis (LE) is an inflammatory disorder of the central nervous system (CNS) that can be of paraneoplastic or primary autoimmune origin. The disorder is characterized by personality changes, emotional disturbances, mental status changes, behavior abnormalities, confusion, memory deficits and seizures.

\section{Materials and methods}

We describe the case of a 79-year old patient with symptoms of LE who presented with high fever, affective changes in personality, auditory hallucinations, memory loss, irrelevant talking and confusion. The brain MRI at admission showed a left hippocampal T2-weighted lesion with meningeal gadolinium-enhancement and the EEG showed periodic lateralized epileptiform discharges (PLEDS) on the left temporal area. Routine blood tests were normal. CSF examination at admission revealed 50 cells/mm3, predominantly polynuclear $(87 \%)$ and 0.74 $\mathrm{g} / \mathrm{l}$ proteins. Polymerase chain reaction for herpes virus 1 to 3, 6 and enterovirus were negative. The patient was treated with acyclovir but three weeks later he developed myoclonia with secondary generalized epileptic seizures. The serum was negative for paraneoplastic antibodies including $\mathrm{Hu}$, Yo, Ri, CV2/CRMP5, Amphiphysin, Ma2/ Ta.

\section{Results}

Despite the anti-epileptic treatment, the patient's symptoms deteriorated. MRI showed new lesions. The EEG showed a new focus of right parietal PLEDS. Serum voltage-gated potassium channel antibodies (VGKC-Ab) were detected at high levels (3.495 pM). Steroids and plasma exchange were initiated with marked and sustained improvement of neuropsychological function. This clinical improvement correlated with both EEG and radiological amelioration.

\section{Conclusions}

Limbic encephalitis associated with positive VGKC-Ab is a rare condition usually of non-paraneoplastic autoimmune origin. Patients presenting with symptoms mimicking viral or paraneoplastic limbic encephalitis, should be promptly investigated for VGKC-associated encephalopathy. A marked clinical and paraclinical improvement, such as observed with this patient, is usually seen when immunosuppressive therapy is rapidly initiated.

\section{References}

I. Angela Vincent, Buckley Camila, Schott Jonathan M., Baker lan, Dewar Bonnie-Kate, Detert Niels, Clover Linda, Parkinson Abigail, Bien Christian G, Omer Salah, Lang Bethan, Martin N: Rossor and Jackie Palace. Potassium channel antibody-associated encephalopathy: a potentially immunotheraspy-responsive form of limbic encephalitis. Brain 2004, I 27(3):70I-7I 2.

2. Urbach H, Soeder M.S, Jeud M, Klockgether T, Meyer B, Bien G.C.: Serial MRI of limbic encephalitis. Neuroradiology 2006, 48:380-386. 
3. Thieben M.J, Lennon V.A., Boeve B. F, Aksamit A.J, Keegan M, Vernino $S$ : Potentially reversible autoimmune limbic encephalitis with neuronal potassium channel antibody. Neurology 2004, 62: $1177-1182$

Publish with Bio Med Central and every scientist can read your work free of charge

"BioMed Central will be the most significant development for disseminating the results of biomedical research in our lifetime. " Sir Paul Nurse, Cancer Research UK

Your research papers will be:

- available free of charge to the entire biomedical community

- peer reviewed and published immediately upon acceptance

- cited in PubMed and archived on PubMed Central

- yours - you keep the copyright

Submit your manuscript here:

http://www.biomedcentral.com/info/publishing_adv.asp 